\title{
EFFECT OF SODIUM CHLORIDE SODIUM NITRITE AND ASCORBIC ACID ON THE MICROBIOLOGICAL QUALITY OF SUN-DRIED AND FREEZE-DRIED BUFFALO MEAT \\ Talib, M.A. ${ }^{*}$; A.M. Alian ${ }^{2}$ and N.A. Salama ${ }^{2}$ \\ 1* Department of Biology, Faculty of Pure and Applied Science, University of Ndjamena, P.O.Box 1027, Chad. \\ 2 Food Techology Department, Faculty of Agriculture, Cairo University, Egypt.
}

\begin{abstract}
Meat slices were soaked in three different levels (5, 10 and $15 \%)$ of sodium chloride $(\mathrm{NaCl})$, each containing $(100 \mathrm{ppm})$ sodium nitrite or $(400 \mathrm{ppm})$ ascorbic acid, for 30 minutes at room temperature $\left(30^{\circ} \mathrm{C}\right)$. Meat slices were divided into two equal batches and subjected to sun drying or freeze drying process. Sun dried meat samples were then grounded into powder. Both meat samples were packed in polyethylene bags and kept in plastic container for six months at room temperature. Untreated meat samples were used as control. Meat samples were taken during sun drying and storage for microbiological analysis (total count, coliforms, Staphylococci, Streptococci and moulds and yeasts). Freeze-dried meat samples were taken only during storage. Results show that soaking meat samples in $\mathrm{NaCl}$ or preservatives revealed a gradual decrease in total $\log \mathrm{No} / \mathrm{g}$. Grinding process increased the number of micro organisms in sun dried meat. $5 \% \mathrm{NaCl}$ or combined with preservative decreased slightly the bacterial Log No/g in both types of meat during processing and storage. Meat samples treated with (10 and $15 \%) \mathrm{NaCl}$ or preservatives inhibited bacterial growth during storage. Combination of $\mathrm{NaCl}$ and preservatives showed a noticeable effect in decreasing bacterial log No/g compared to $\mathrm{NaCl}$.
\end{abstract}

\section{INTRODUCTION}

Plant and animal foods, have been successfully preserved by the process of drying. In recent years, sun drying, spray drying, oven and cabinet drying have been practiced (Kuponiyi et al., 1984). Drying process reduced the water activity $(\mathrm{aW})$ of the meat, which results in reduction in number of surviving micro organisms. Some spore forming organisms might survive these conditions and remained to contaminate the dried meat. Most of contaminants found in dried meat resulted from the contamination, because the procedure of handling the dried meat were no better than those used in handling the fresh meat (Faparusi, 1981).

Sun dried meat is called locally in some African countries Sharmoot. Sharmoot is traditionally prepared by cutting beef into strips, then sun dried for 3 to 5 days and grounded into powder. This procedure results in an extensive contamination by microorganisms and dirts (Gailani, 1988). The development of sound science-based methods to assure the production of high-quality and nutritious meat is needed. Such product also must be free of pathogenic microorganisms to assure their success in production and marketing (Chang et al., 1996).

1* Author to whom correspondence should be addressed.

Tel.: (235) 6447724 Fax: (235) 524033 E-mail: mohamed.talib@yahoo.fr 
Talib, M.A. et al.

A variety of additives which have the potential for inhibiting the microorganisms have been investigated (Brew et al., 1995). Sodium chloride is commonly employed in conjunction with drying, and its useful in controlling microbial growth during sundrying and dehydration (Desrosier, 1963 and Whiting et al., 1984). Nitrite has been a valuable antibotulinal agent in cured meats and may offer some protection from the pathogens (Archer, 2002). Sodium nitrite is the source of nitric oxide, which is the real colour fixative, and has some bacteriostatic effect in acid solution. Ascorbic acid knows to act both as an antioxidant, and as a pro-oxidant in meat systems under certain conditions. At low levels (100 ppm) ascorbic acid catalyses the development of oxidative rancidity as indicated by increased Thiobarbituric acid (TBA) values (Sato and Hegarty, 1971 and Ratty and Das, 1986).

Freeze-drying, a process based in the subsequent ice sublimation of the product, achieving a very high retention of both sensory and nutritional qualities (de Penna et al., 1995). Freeze-drying is the method that is practiced for meat dehydration and according to the decrease in water activity (aW), this process is considered as one of the best method for meat dehydration. It is used for a number of foods, including meat poultry, sea food, fruits and vegetables (Frazier, 1984).

The objective of the current research was to determine the effect of sun- drying, freeze- drying and preservatives (sodium chloride, sodium nitrite and ascorbic acid) on the hygienic-sanitary conditions and microbiological quality of buffalo meat during processing and storage.

\section{MATERIALS AND METHODS}

\section{Experimental Design:}

The experiment was conducted using $2 \times 3 \times 7$ factorial arrangement in a completely randomized design with three replication. The factors were 2 dehydration process (sun drying and freeze drying), 3 preservatives of sodium chloride, sodium nitrite and ascorbic acid and 7 sampling times $(0,2$, 4 days of sun drying) than at $(0,2,4,6$ months) of storage for sun-dried meat samples. However; freeze-dried meat samples were taken only during storage.

Hind quarters of buffalo meat containing semimembranosus, semitendionsus, performeris and intercostal musles were used in this study. They were obtained from three years buffalo male, from the Faculty of Agriculture, Cairo, Egypt. Fresh meat trimmings were differentiated into visually lean and fat portion and kept in the refrigerator at $\left(5 \pm 1^{\circ} \mathrm{C}\right)$ for 24 hours. The fresh muscles were cut approximately into $30 \times 2 \times 0.5 \mathrm{~cm}$ dimensions.

\section{Preparation of Dipping Solutions:}

Three different solutions of sodium chloride were prepared. Sodium chloride was weighed at three units of 50,100 and $150 \mathrm{~g}$. Each unit weight was dissolved in $1000 \mathrm{ml}$ (1 Litre) of water. The second solution was prepared as previously described, each containing $0.1 \mathrm{~g} / \mathrm{l}$ sodium nitrite. The third solution was prepared similarly to the second, each containing $0.4 \mathrm{~g}$ ascorbic acid/1. 


\section{Dip Treatment and Drying:}

Meat slices were soaked in three different solutions for 30 minutes, then divided into two equal batches. Samples of meat in the first batch were subjected to sun- drying for 4 days, then grounded into powder. Meat samples in the second batch were grounded and frozen at $-30^{\circ} \mathrm{C}$ for 24 hours then freeze - drying process was carried out using (Alpha 1 - 20) Christ Freeze - drier under vacuum at $0.05 \mathrm{~mm} \mathrm{Hg}$.

\section{Packaging and Storage:}

Both meat samples were packed in polyethylene bags and kept in plastic containers for six months at room temperature.

\section{Sampling:}

Meat samples were taken after 30 minutes of dipping (zero time) then after 2 and 4 days of sun drying thereafter $0,2,4$ and 6 months of storage, for the microbiological analysis of sun dried and freeze dried buffalo meat.

\section{Microbiological Analysis and Samples Preparation:}

Twenty five grams of each treatment was aseptically removed and minced with sterile sand in a porcelain dish then transferred to $225 \mathrm{ml}$ buffer peptone water in a $500 \mathrm{ml}$ flask. Appropriate decimal dilutions $f$ the sample were prepared in 0.1 percent sterile peptone water, $1 \mathrm{ml}$ portion of each dilution pippetted into separate sterile Petri dishes. Some $15 \mathrm{ml}$ of plate count agar, Baird Parker agar, Azide - Dextrose agar, Mac- Conkey agar and Sabraud agar were added to each plate for total aerobic plate count, Staphylococci count, Streptococci count, coliforms count and molds and yeasts counts, respectively. The plates were mixed gently and allowed to incubate for 24 hours at $37^{\circ} \mathrm{C}$ and 25 to $30^{\circ} \mathrm{C}$ for five days for molds and yeasts counts. Colonies wee counted using colony counter (Adesiyun et al., 1983).

\section{Statistical Analysis:}

The microbial counts were presented as means expressed as log No/g.

\section{RESULTS AND DISCUSSION}

The total aerobic count in Table 1 revealed that the bacterial $\log \mathrm{No} / \mathrm{g}$ in fresh buffalo meat was 4.6. Soaking fresh meat samples in sodium chloride solutions decreased the $\log \mathrm{No} / \mathrm{g}$ to $3.6,3 / 14$ and 2.14 with raising $\mathrm{NaCl}$ concentrations 5,10 and $15 \%$, respectively. After four days of drying the long No/g reached 2.66, 1.34 and 0.00 for 5,10 and $15 \% \mathrm{NaCl}$ concentration, respectively. The decrease has been explained by (Desrosier, 1963 and Whiting et al., 1984). Also Talib et al. (2006) reported that as the $\mathrm{NaCl}$ concentrations in dipping solutions increased the rate of moisture removal during sun-drying increased too, and this is useful in controlling microbial growth. Grinding process increased slightly the microbial log No/g of sun dried meat. Mates (1983) attributed this to grinding process that distributes bacteria on the surface throughout the entire product, and creates an ideal condition for multiplication, also, he found that the bacterial log No/g decreased as the storage period progressed.

Combination of $\mathrm{NaCl}$ and preservatives showed a noticeable effect in decreasing bacterial log $\mathrm{No} / \mathrm{g}$ compared to $\mathrm{NaCl}$. Bacterial growth was not 
Talib, M.A. et al.

observed during storage period in meat samples treated with 10 and $15 \%$ $\mathrm{NaCl}$ or preservatives, this was due to the incapacity of these pathogens to compete with high concentration of $\mathrm{NaCl}$ and preservatives. Similarly Salama and Khalafalla (1987) found that addition of sodium nitrite at $80,120 \mathrm{ppm}$ and ascorbic acid at $0.2 \%$ wee sufficient in reducing micro flora during meat processing. Similar findings wee reported by Romminger et al. (1982) when they used 10 and $100 \mathrm{ppm}$ sodium nitrite in sausage.

The bacterial log No/g increased after 4 months of storage in meat samples treated with $5 \% \mathrm{NaCl}$ or preservatives, this may be due in part to the increase in moisture content. Treating meat samples with 5, 10 and $15 \%$ $\mathrm{NaCl}$ and preservatives inhibited growth of Staphylococci, Streptococci, coliforms and moulds and yeasts during processing and storage, except in the control. However, Gailani (1988) reported that combination of water activity and sub inhibitory levels of antimicrobial agents were effective in inhibiting bacteria. The Log No/g of microbial total count in untreated meat samples declined gradually during four days of sundrying from 4.60 to 4.26 , then increased gradually during six months of storage from 4.37 at zero time to 4.87. Adesiyun (1983) found that Staphylococci counts of dried beef stored at room temperature for 28 days declined from $9.9 \times 10^{5}$ to $3.0 \times 10^{3}$ $\mathrm{CFU} / \mathrm{g}$.

From the results in Table 2 freeze-dried meat samples treated with 5\% sodium chloride or combination of preservatives decreased gradually during six months of storage from 2.43 to 0.77 and from 2.34 to 0.00 , respectively. These microorganisms were completely inhibited after four months of storage in samples treated with $10 \% \mathrm{NaCl}$ or combination of preservatives. Also, treating meat samples with $15 \% \mathrm{NaCl}$ and preservatives inhibited all bacterial growth during processing and storage.

Staphylococci, Streptococci, coliforms and molds and yeasts were completely inhibited during processing and storage, except in the control. Previous report by Rawal et al. (1973) indicated that no pathogens or coliforms were detected in freeze dried mutton meat stored for two years. The elimination of these microorganisms could be attributed also to the variety of additives stated by Brew et al. (1995) and Archer (2002). Untreated meat samples demonstrated a gradual decrease in Log No/g during six months of storage from 2.44 to 2.07 .

No difference was observed between both meat samples treated with sodium chloride and sodium nitrite and those treated with the combination of sodium chloride, sodium nitrite and ascorbic acid. However, incorboration of ascorbic acid did not show a noticeable effect in decreasing the number of bacteria. 
J. Agric. Sci. Mansoura Univ., 32 (9), September, 2007 


\section{CONCLUSION}

Water activity is recommended as parameter for controlling the bacterial growth in meat products. Combination of sodium chloride and preservatives is useful in controlling microbial growth during sun drying and dehydration process. Salt over $5 \%$ controlled growth of micro organisms. Although studies in other countries indicated high prevalence of Staphylococci, Streptococci, coliforms and molds and yeasts in sun dried meats (Gailani, 1988 and Bennani et al., 1995) no isolates were obtained from any of the tested samples, in this study.

\section{REFERENCES}

Adesiyun, A.A. (1983). Effect of storage and consumer handling on Staphylococcal counts of dried beef and dried Fish. J. of Food Prot., 47(5): $352-353$.

Archer, D.L. (2002). Evidence that ingested nitrate and nitrite are benefical to ealth. J. of Food Prot., 65(5): $872-875$.

Bennani, L., Zenati, Y., Faid, M. and Ettayebi, M. (1995). Physico-chemical and microbiological characteristics of a dried salted meat product (Kaddid) in Morocco. 1: Z Lebensm Unters Forsch 201(6): 528 - 532.

Brewer, M.S., Bharati, K.R., Argoudelis, L. and Sprouls, G.K. (1995). Sodium lactate and sodium chloride effects on aerobic plate counts and colour or aerobically packed ground pork. J. of Food Sci., 60(1): $58-62$.

Chang, S.F., Huang, T.C. and Pearson, A.M. (1996). Control of the dehydration process in production of intermediate- moisture meats products: a Review. 1: Advc. Food Nutr. Res. 39: 71-161.

De Penna, E., Kutscher, V., Bunger, A., Lopez, L. and Santana, R. (1995). Manufactured of freeze-dried stew for mountaineers. 1: Arch Latinoam Nutr., 45(1): $67-75$.

Desrosier, W.N. (1963). The technology of food preservation. The AVI Publishing Company, Inc. pp: 128, 129, 144, 145.

Faparussi, S.I. (1981). Identity of microorganisms from Khundi - a smoked meat. J. of Food Prot., 44(8): 581 - 582.

Frazier, W.C. and Westhoff, D.C. (1984). Food Microbiology. 3dㅡ Edition pp: $41,160$.

Gailani, M.B. (1988). Water activity in relation to microbiology during processing and storage of Sudanese dried beef (Sharmoot). Dissertation Abstracts International, B. 46(8): 2513 - 2514. Kansas, 66506 USA.

Kuponiyi, O.A. Tuki, A.F., Makanju, A. and Olaofe, O. (1984). Effect of spray drying on the chemical composition of some Nigerians foods. J. Nut. $5(1): 49-51$.

Mates, A. (1983). Microbiological survey of frozen ground meat and a proposed standard. J. of Food Prot., 46(2): 87 - 89. 
Ratty, A.K. and Das, N.P. (1986). Lipid peroxidation in the rat brain mitochondria in the presence of ascorbic acid. IRCS Medical Science, 14: $815-816$.

Rawal, T.N. Roy, L.B., Chaudhary, B.S., Sharma, R.N. and Sharma. T.R. (1973). Quality of A.F.D. meat during storage. J. of Food Sci. and Technol., India, 10(4): $153-155$.

Romminger, G., Jeschke, G. and Pillinglt, I. (1982). Problems with the red colour of meat. II- Effects of reduction of nitrite addition on quality characteristics of Brushwurst sausage. VEBF Leish Kombinat, Dresden, German Democratic Republic. Flesich, 36(11): 215 - 217.

Salama, N.A. and Khlaphalla, G.M. (1987). Microbiological and chemical studies during Basterma cured meat processing. Archive Fur Lebensmittel Hygiene, 38: $33-68$.

Sato, K. and Hegarty, G.R. (1971). Warmed over flavour in cooked meats. J. Food Sci., 36: 1098 - 1102.

Talib, M.A., Allian, A.M. and Salama, N.A. (2006). Effect of dehydration and preservatives on physicochemical properties of sun-dried and freezedried buffalo meat. J. Agric. Sci. Mansoura Univ., 31(11): 6959 - 6965.

Whiting, R.C., Benedict, R.C., Kunsh, C.A. and Woychik, J.H. (1984). Effect of sodium chloride levels in Frankfurters on the growth of Clostridium sporogenes and Staphylococcus aureus. J. of Food Sci., 49: 351.

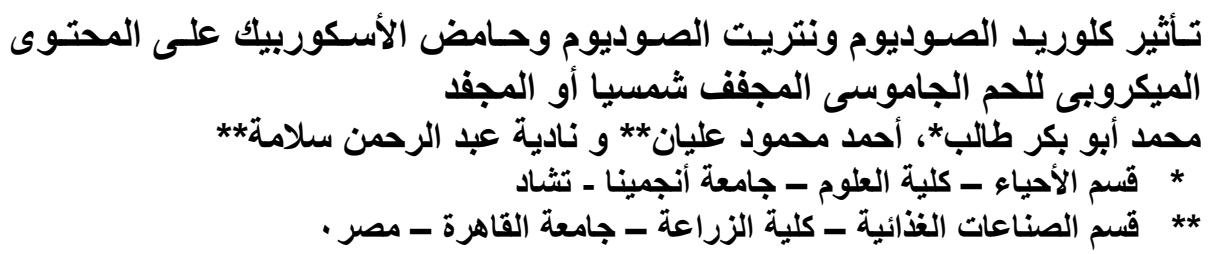

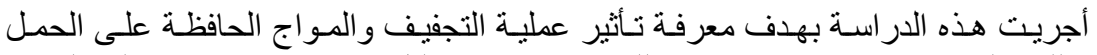

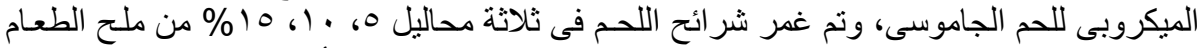

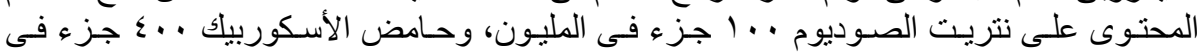

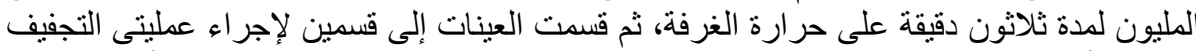

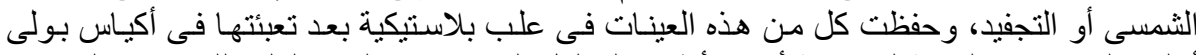

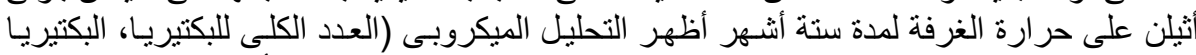

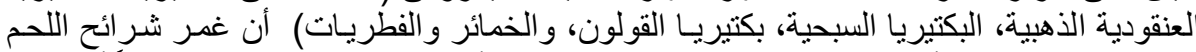

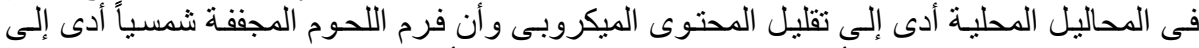

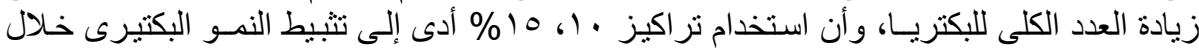

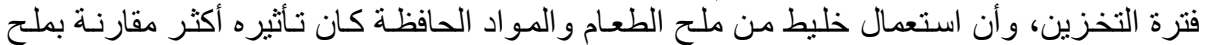

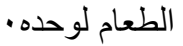


Table 1: Log No/g of microbial total count of sun-dried meat during processing and storage for six months at room temperature.

\begin{tabular}{|c|c|c|c|c|c|c|c|c|c|c|}
\hline \multirow[b]{3}{*}{ Sampling } & \multirow[b]{3}{*}{$\begin{array}{l}\text { Untreated } \\
\text { sample }\end{array}$} & \multicolumn{9}{|c|}{ Concentration of $\mathrm{NaCl}$ for samples dipped in } \\
\hline & & \multicolumn{3}{|c|}{$5 \%$} & \multicolumn{3}{|c|}{$10 \%$} & \multicolumn{3}{|c|}{$15 \%$} \\
\hline & & $\mathrm{NaCl}$ & $\begin{array}{c}\mathrm{NaCl} \\
{ }^{*} \mathrm{NaNO}_{2}\end{array}$ & $\begin{array}{c}\mathrm{NaCl} \\
\mathrm{NaNO}_{2} \\
{ }^{* *} \text { Ascorbic } \\
\text { acid } \\
\end{array}$ & $\mathrm{NaCl}$ & $\begin{array}{c}\mathrm{NaCl} \\
\mathrm{NaNO}_{2}\end{array}$ & $\begin{array}{c}\mathrm{NaCl} \\
\mathrm{NaNO}_{2} \\
\text { Ascorbic } \\
\text { acid } \\
\end{array}$ & $\mathrm{NaCl}$ & $\begin{array}{c}\mathrm{NaCl} \\
\mathrm{NaNO}_{2}\end{array}$ & $\begin{array}{c}\mathrm{NaCl} \\
\mathrm{NaNO}_{2} \\
\text { Ascorbic } \\
\text { acid } \\
\end{array}$ \\
\hline During processing & & & & & & & & & & \\
\hline Zero-time & 4.60 & 3.60 & 3.17 & 3.17 & 3.14 & 3.15 & 3.15 & 2.14 & 2.10 & 2.12 \\
\hline Two days & 4.84 & 3.29 & 3.07 & 3.07 & 2.92 & 2.86 & 2.90 & 0.83 & 0.60 & 0.00 \\
\hline $\begin{array}{l}\text { Four days } \\
\text { During storage }\end{array}$ & 4.26 & 2.66 & 2.46 & 2.50 & 1.34 & 1.14 & 1.11 & 0.00 & 0.00 & 0.00 \\
\hline Zero-time & 4.37 & 2.77 & 2.53 & 2.59 & 1.41 & 1.26 & 1.29 & 0.00 & 0.00 & 0.00 \\
\hline Two months & 4.47 & 2.62 & 2.32 & 2.38 & 0.00 & 0.00 & 0.00 & 0.00 & 0.00 & 0.00 \\
\hline Four months & 4.60 & 1.53 & 1.23 & 1.25 & 0.00 & 0.00 & 0.00 & 0.00 & 0.00 & 0.00 \\
\hline Six months & 4.87 & 1.70 & 1.53 & 1.45 & 0.00 & 0.00 & 0.00 & 0.00 & 0.00 & 0.00 \\
\hline
\end{tabular}

${ }^{*} \mathrm{NaNO}_{2}$ added at $100 \mathrm{ppm}$

${ }^{\star *}$ Ascorbic acid added at $400 \mathrm{ppm}$.

Table 2: Log No/g of microbial total count of freeze-dried meat during storage for six months at room temperature.

\begin{tabular}{|c|c|c|c|c|c|c|c|c|c|c|}
\hline \multirow[b]{3}{*}{ Sampling } & \multirow{3}{*}{$\begin{array}{l}\text { Untreated } \\
\text { sample }\end{array}$} & \multicolumn{9}{|c|}{ Concentration of $\mathrm{NaCl}$ for samples dipped in } \\
\hline & & \multicolumn{3}{|c|}{$5 \%$} & \multicolumn{3}{|c|}{$10 \%$} & \multicolumn{3}{|c|}{$15 \%$} \\
\hline & & $\mathrm{NaCl}$ & $\begin{array}{c}\mathrm{NaCl} \\
{ }^{*} \mathrm{NaNO}_{2}\end{array}$ & $\begin{array}{c}\mathrm{NaCl} \\
\mathrm{NaNO}_{2} \\
{ }^{* *} \text { Ascorbic } \\
\text { acid }\end{array}$ & $\mathrm{NaCl}$ & $\begin{array}{c}\mathrm{NaCl} \\
\mathrm{NaNO}_{2}\end{array}$ & $\begin{array}{c}\mathrm{NaCl} \\
\mathrm{NaNO}_{2} \\
\text { Ascorbic } \\
\text { acid }\end{array}$ & $\mathrm{NaCl}$ & $\begin{array}{c}\mathrm{NaCl} \\
\mathrm{NaNO}_{2}\end{array}$ & $\begin{array}{c}\mathrm{NaCl} \\
\mathrm{NaNO}_{2} \\
\text { Ascorbic } \\
\text { acid }\end{array}$ \\
\hline Zero-time & 2.44 & 2.43 & 2.30 & 2.34 & 2.17 & 2.00 & 2.02 & 0.00 & 0.00 & 0.00 \\
\hline Two months & 2.36 & 2.27 & 2.17 & 2.07 & 0.95 & 0.90 & 0.84 & 0.00 & 0.00 & 0.00 \\
\hline Four months & 2.39 & 1.11 & 1.00 & 1.00 & 0.00 & 0.00 & 0.00 & 0.00 & 0.00 & 0.00 \\
\hline Six months & 2.07 & 0.77 & 0.00 & 0.00 & 0.00 & 0.00 & 0.00 & 0.00 & 0.00 & 0.00 \\
\hline
\end{tabular}

$* \mathrm{NaNO}_{2}$ added at $100 \mathrm{ppm}$

$\begin{array}{cccc}0.00 & 0.00 & 0.00 \\ \end{array}$ 